E3S Web of Conferences 1, 11006 (2013)

DOI: $10.1051 / \mathrm{e} 3 \operatorname{sconf} / 20130111006$

(c) Owned by the authors, published by EDP Sciences, 2013

\title{
Assessment of Heavy Metals in Bivalves Molluscs of Apulian Region: a 3-years control activity of a EU Laboratory
}

\author{
O. Miedico, C. Pompa, M. Tarallo and A. E. Chiaravalle \\ Department of Chemistry, Istituto Zooprofilattico Sperimentale - Puglia e Basilicata, Foggia, ITALY \\ izsfgchimica@tiscali.it
}

\begin{abstract}
The bivalve molluscs represent an important matrix to be studied for several reasons. Their nutritional properties make them valuable to the consumers, so that their consumption and commercial value has risen worldwide. Simultaneously, their significant water-filtering capability and their persistence in the same place make them good bio-indicators of marine ecosystems. The presence of the heavy metal contaminants, as $\mathrm{Cd}, \mathrm{Pb}$ and $\mathrm{Hg}$, was investigated in bivalve molluscs such as mussels (Mytilus galloprovincialis), clams (Venus gallina) and oysters (Ostrea edulis). In the present study, a survey was carried out on 334 samples addressed to the Istituto Zooprofilattico Sperimentale - Puglia e Basilicata, Foggia (ITALY) between 2009-2011, and collected by official authorities along the coasts of Apulia Region. The conformity of heavy metal content in bivalve molluscs was verified, in according to EC Reg. 1881/2006. The compliance was found for the total amount of samples. The obtained data on heavy metals concentration in bivalve molluscs were compared with data found in monitoring studies on the incidence of heavy metals in 1981 in North-Western Mediterranean Sea, in 2003 in Tyrrhenian Sea and in 2010 in Pacific Ocean (Chile), reported in literature. The information obtained from this work offer an essential database, not only for the authorities involved in food control, but also for the official institutions responsible of a constant control of the marine ecosystem pollution.
\end{abstract}

Key words: Heavy metals, ICP-MS, bivalve molluscs, bio-indicators

\section{Introduction}

The bivalve molluscs are the second class of molluscs by number of species (about 30.000). This class includes mussels (Mytilus galloprovincialis), clams (Venus gallina), oysters (Ostrea edulis) and other edible species. Bivalve molluscs are very much appreciated by consumers for their nutritional properties, and their consumption has increased worldwide [J. Oliveira et al, 2011]. The average annual consumption of bivalve molluscs, in Italy, is $12 \%$ of the total annual consumption of fresh fish, and in the Apulia Region the consumption of mussels, clams and oysters was 21.691, 236, 956 (in tons), respectively. For these reasons, these food products are involved in the main sanitary control plans of the Italian health system. The content of the main inorganic contaminants, as $\mathrm{Cd}, \mathrm{Pb}$ and $\mathrm{Hg}$ has been regulated by European Union (EC Reg. 1881/2006).

Bivalve molluscs are suspension feeders, that selectively filter small particles, phytoplankton zooplankton and inorganic matter from the surrounding water (mussels filter about $36 \mathrm{l} / \mathrm{die}$ of water and oysters filter up to $350 \mathrm{l} / \mathrm{die})$. This aspect, together with their persistence in the same place, makes them excellent bio-indicators of the pollution level of the marine ecosystem [R. Eister, 1981; P. S. Rainbow, 195].

\section{Materials and Methods}

The bivalve molluscs samples were collected by official authorities along the coasts of Apulia Region between 2009-2011. The samples were analyzed in the laboratory of the Istituto Zooprofilattico Sperimentale - Puglia e Basilicata, Foggia (ITALY), to assess $\mathrm{Cd}, \mathrm{Pb}$ and $\mathrm{Hg}$ content. 114 samples were analyzed in 2009 (82 mussels, 25 clams, 7 oysters), 129 samples in 2010 (76 mussels, 46 clams, 7 oysters) and finally 91 samples in 2011 (70 mussels, 16 clams, 5 oysters). The analyses were performed using standard methods (EN 13805:2002 "Determination of trace elements - Pressure digestion" and EN 15763:2009 "Determination of Arsenic, Cadmium, Mercury and Lead in foodstuffs by ICP-MS after pressure digestion"). Separation of edible portion of a representative sample and the following 
Table 1. Average concentration of $\mathrm{Cd}, \mathrm{Pb}$ and $\mathrm{Hg}$ in mussels, clams and oysters in 2009-2011. The results are expressed as $\mathrm{mg} / \mathrm{kg}$ of wet weight.

\begin{tabular}{|c|c|c|c|c|c|c|c|c|c|c|c|}
\hline \multirow[b]{2}{*}{ Year } & \multirow[b]{2}{*}{ Species } & \multirow[b]{2}{*}{$\mathbf{N}$} & \multicolumn{3}{|c|}{ Cd } & \multicolumn{3}{|c|}{$\mathrm{Pb}$} & \multicolumn{3}{|c|}{$\mathrm{Hg}$} \\
\hline & & & Mean & STD & Min-max & Mean & STD & Min-max & Mean & STD & Min-max \\
\hline \multirow{3}{*}{2009} & M. Galloprov. & 82 & 0,157 & 0,102 & $0,055-0,86$ & 0,187 & 0,122 & $0,095-0,78$ & 0,019 & 0,016 & $0,006-0,027$ \\
\hline & V. gallina & 25 & 0,160 & 0,106 & $0,048-0,56$ & 0,114 & 0,095 & $0,073-0,55$ & 0,017 & 0,016 & $0,006-0,024$ \\
\hline & O. edulis & 7 & 0,450 & 0,199 & $0,210-0,73$ & 0,131 & 0,115 & $0,035-0,370$ & 0,011 & 0,009 & $0,006-0,017$ \\
\hline \multirow{3}{*}{2010} & M. Galloprov. & 76 & 0,120 & 0,085 & $0,049-0,384$ & 0,194 & 0,104 & $0,079-0,542$ & 0,018 & 0,013 & $0,006-0,025$ \\
\hline & V. gallina & 46 & 0,124 & 0,076 & $0,041-0,268$ & 0,174 & 0,097 & $0,064-0,413$ & 0,023 & 0,013 & $0,006-0,025$ \\
\hline & O. edulis & 7 & 0,436 & 0,236 & $0,151-0,990$ & 0,200 & 0,107 & $0,065-0,400$ & 0,010 & 0,008 & $0,006-0,018$ \\
\hline \multirow{3}{*}{2011} & M. Galloprov. & 70 & 0,135 & 0,123 & $0,042-1,11$ & 0,206 & 0,095 & $0,051-0,504$ & 0,017 & 0,013 & $0,006-0,026$ \\
\hline & V. gallina & 16 & 0,115 & 0,153 & $0,054-0,652$ & 0,158 & 0,176 & $0,044-0,797$ & 0,011 & 0,006 & $0,006-0,021$ \\
\hline & O. edulis & 5 & 0,470 & 0,317 & $0,071-0,952$ & 0,104 & 0,039 & $0,052-0,158$ & 0,025 & 0,026 & $0,006-0,064$ \\
\hline
\end{tabular}

homogenization were previously carried out. About $1 \mathrm{~kg}$ of bivalve molluscs with shells has been taken to obtain $0.2 \mathrm{~kg}$ of unshelled mussels, $0.15 \mathrm{~kg}$ of unshelled clams and $0.1 \mathrm{~kg}$ of unshelled oysters. A microwave-assisted digestion by a nitric acid $\left(\mathrm{HNO}_{3}\right)$ and hydrogen peroxide $\left(\mathrm{H}_{2} \mathrm{O}_{2}\right)$ was carried out on a small quantity of homogenized sample (about $1.0 \mathrm{~g}$ ). The contaminants of interest were detected by ICP-MS (Inductively Coupled Plasma Mass Spectrometry, PerkinElmer ELAN DRC II, equipped with Dynamic Reaction Cell).

The signal of $\mathrm{Pb}$ as sum of $\mathrm{Pb}-206, \mathrm{~Pb}-207$ and $\mathrm{Pb}-208$ isotopes, $\mathrm{Cd}$ as $\mathrm{Cd}-111$ isotope (less abundant but not interfered by $\mathrm{Tin}-114$ ) and $\mathrm{Hg}$ as $\mathrm{Hg}$-202 isotope was monitored. Those ions were measured in standard mode. The calibration was performed with aqueous working solutions. $1000 \mathrm{mg} / \mathrm{l}$ standard stock solutions of $\mathrm{Cd}, \mathrm{Pb}$ and $\mathrm{Hg}$ were purchased from the ICP-International. Certified Reference Materials used as internal quality control were ERM-CE 278 mussel tissue supplied by IRMM and NIST 1566 oyster tissue supplied by NIST.

\section{Results and Discussion}

A summary of the results are shown in Table 1. Although a widespread occurrence of heavy metals contamination was observed, the totality of the samples examined during the 3 years is within the limits stated in the EC Reg. $1881 / 2006(1,0 \mathrm{mg} / \mathrm{kg}$ for $\mathrm{Cd}, 1.5 \mathrm{mg} / \mathrm{kg}$ for $\mathrm{Pb}$ and $0.50 \mathrm{mg} / \mathrm{kg}$ for $\mathrm{Hg}$ ), underlining the fair degree of safety for the consumers health protection. However, on the basis of the described bio-indicator property, it is possible to derive some interesting conclusions about the contamination level in the Apulian coasts and its temporarily evolution.

The different bioaccumulation capability of the 3 species investigated can be observed, however not represented by the same number of samples analyzed. Despite the considerable physiological similarities, the 3 species of shellfish show a significantly different bioaccumulation degree, depending also of the type of contaminant. In particular, mussels and clams show a comparable level of $\mathrm{Cd}$ contamination in the considered 3 years. The mussels show a $\mathrm{Pb}$ content significantly higher than the clams, especially in the 2009 and 2011. Oysters show a certain variability of $\mathrm{Pb}$ content, but a significantly high $\mathrm{Cd}$ content (3-4 times higher than clams and mussels). In all the analyzed samples $\mathrm{Hg}$ concentration was found just around the quantification limit of analytical method $(0.0063 \mathrm{mg} / \mathrm{kg})$.

As concerning the temporal change of the contamination level, a slight decrease in the levels of $\mathrm{Cd}$ can be notice (from $0.157 \mathrm{mg} / \mathrm{kg}$ of mussels in 2009 to 0.120 and $0.135 \mathrm{mg} / \mathrm{kg}$ in 2010 and 2011); while, a general stability of $\mathrm{Pb}$ levels appears (with a slight increase, from 0.187 to $0, .206 \mathrm{mg} / \mathrm{kg}$ ).

Figure 1 shows $\mathrm{Pb}$ concentration versus $\mathrm{Cd}$ concentration in each sample (removing the outliers). It can be observed that the ratio $\mathrm{Pb} / \mathrm{Cd}$ is $2 / 1$.

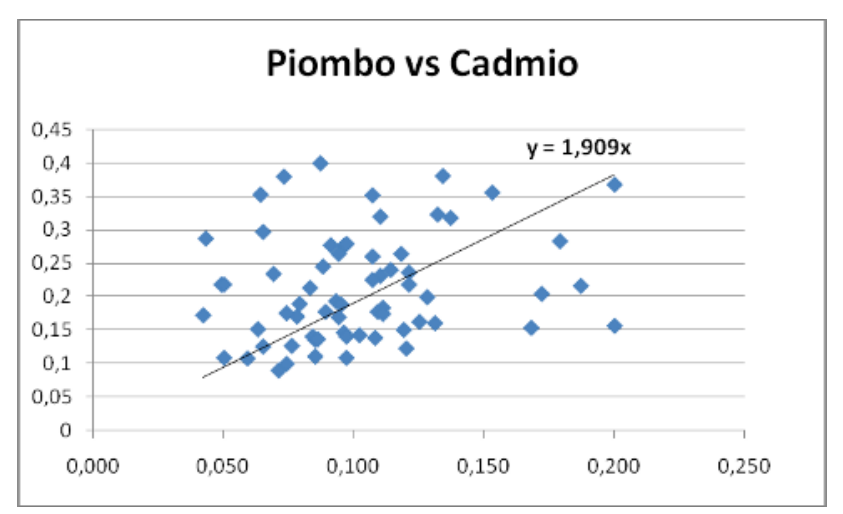

Fig. 1. Correlation between $\mathrm{Pb}$ and $\mathrm{Cd}$ content

For the reasons explained before, the use of molluscs as bio-indicators for trace metal pollution has been largely applied and It is possible to find many work in literature on this practice [R. Eister, 1981; P. S. Rainbow, 195]. Conti and Cecchetti [Conti and Cecchetti, 2003] report the levels of $\mathrm{Pb}$ and $\mathrm{Cd}$ in shellfish sample collected in 
the marine area of the Gulf of Gaeta (Central Tyrrhenian Sea, ITALY). The average concentration of $\mathrm{Cd}$ in those samples is between 0.049 and $0.075 \mathrm{mg} / \mathrm{kg}$ (recalculated value on wet weight, see the reference), and the average data of this work is $0.137 \mathrm{mg} / \mathrm{kg}$, consequently the level of $\mathrm{Cd}$ contamination is significantly higher along the Apulian coast. Instead, the molluscs samples in the Tyrrhenian Sea content $\mathrm{Pb}$ levels from $0, .255$ to $0.380 \mathrm{mg} / \mathrm{kg}$, with comparison to the average values of about $0,196 \mathrm{mg} / \mathrm{kg}$. This is probably due to a different type of anthropogenic pollution of the two Italian coasts. Furthermore, a similar study [L. Hedouin et al, 2010] on the bivalve molluscs samples collected in the North-Western Mediterranean Sea (Spanish coast) shows Cd levels from 0.060 to 0.090 $\mathrm{mg} / \mathrm{kg}$, and very heterogeneously $\mathrm{Pb}$ levels, from 0.40 up to $17.0 \mathrm{mg} / \mathrm{kg}$. Finally, Mendez et al [L. Mendez et al, 2002] found $\mathrm{Pb}$ concentration from 0.066 to 0.61 $\mathrm{mg} / \mathrm{kg}$, in clams collected in Guaymas Bay, Mexico.

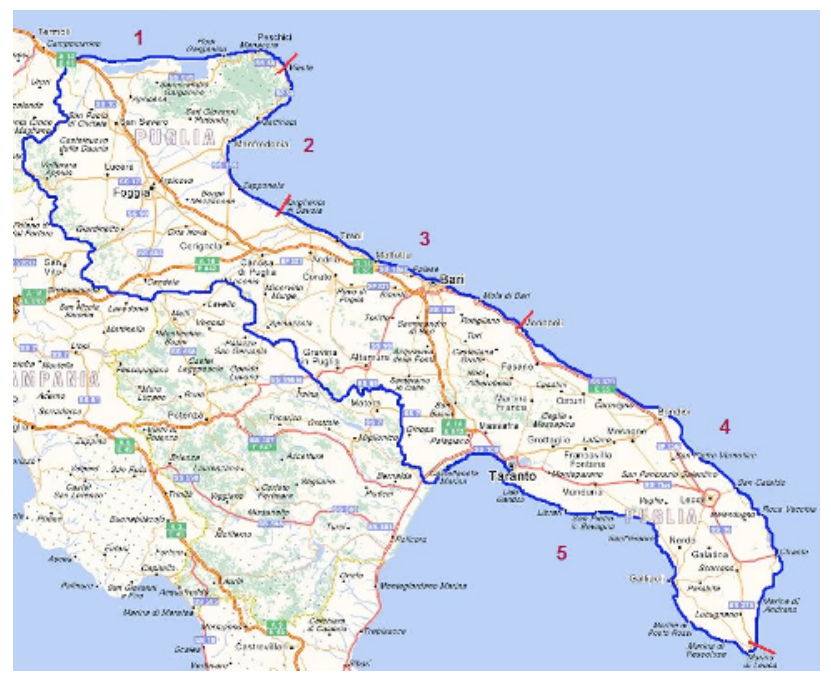

Fig. 2. The coasts of Apulia Region

Because the great extension and the geographic and anthropological diversity, correlation between the different Apulian coasts and the level of heavy metals in the samples analyzed can be found. This study was restricted to mussel species, as they are statistically more represented. For this purpose, 5 coastal areas have been identified:
1) North of Gargano
2) Gulf of Manfredonia
3) Central part of Apulia
4) Southern part of Adriatic Sea
5) Ionian Sea

The results are presented in the Figure 3 and Figure 4. In the 3 years, Cd content was constantly lower in zones $\mathrm{n} .4$ and $\mathrm{n} .5$ (about $0.100 \mathrm{mg} / \mathrm{kg}$ ) compared with zones n.1, 2 and 3 , characterized by variable average results, ranging from 0.128 to $0.200 \mathrm{mg} / \mathrm{kg}$.

Figure 4 shows the average concentrations of $\mathrm{Pb}$, with a more homogeneous contamination trend among the 5 different areas, but, especially in the years 2010 and 2011 , the most contaminated samples belong to the area n.5. Zones 2 and 3 are always the least contaminated of the Apulian coasts.

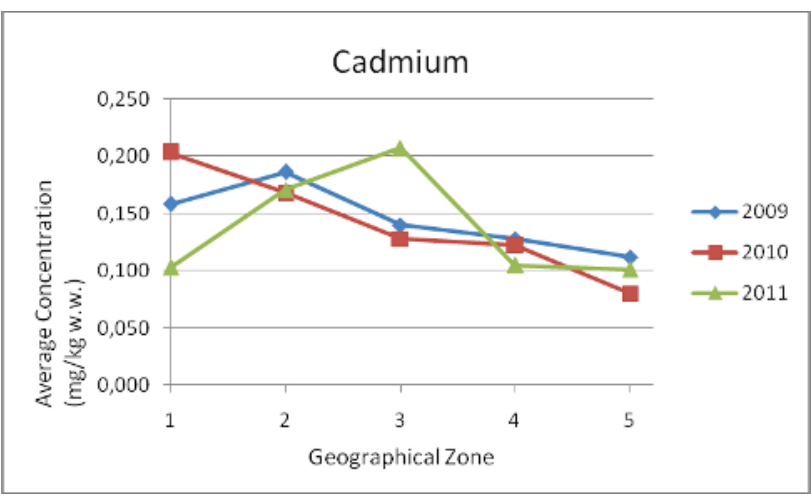

Fig. 3. Average content of $\mathrm{Cd}$ in mussels in 5 different Apulian areas

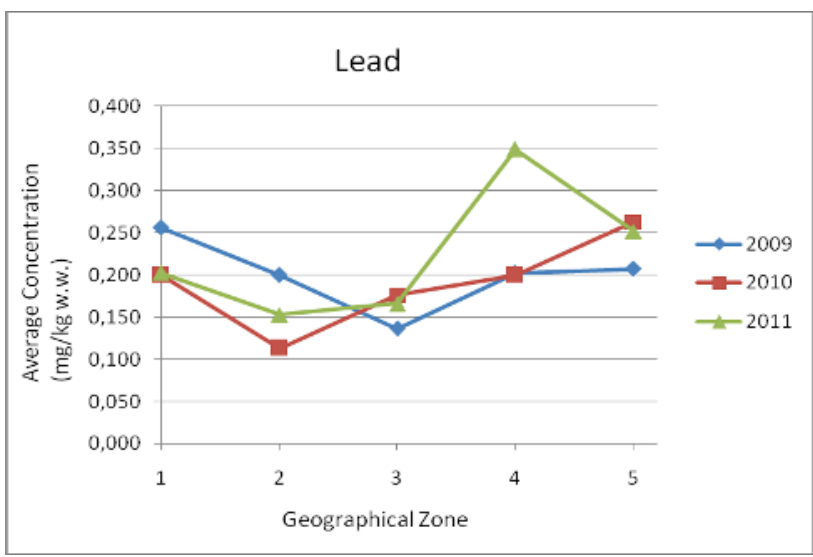

Fig. 4. Average content of $\mathrm{Pb}$ in mussels in 5 different Apulian areas

\section{Conclusion}

The levels of $\mathrm{Cd}$ and $\mathrm{Pb}$ contamination in the Apulian coasts do not arouse preoccupation concerning the health, because in the 3 years under review, only one sample showed a level of $\mathrm{Cd}$ close to the allowed limit $(1.11 \pm$ $0.21 \mathrm{mg} / \mathrm{kg}$ of wet weight). Then, the levels of $\mathrm{Hg}$ are negligible when compared with the allowed limit $(0.50$ $\mathrm{mg} / \mathrm{kg}$ ), probably because the bivalve molluscs occupy a very low position along the food chain, so they cannot bio-accumulate this contaminant.

Furthermore, a comparison with literature data shows a significant difference in the level of $\mathrm{Cd}$ : the Central Tyrrhenian Italian coasts and the North-Western Mediterranean ones show levels of $\mathrm{Cd}$ higher than the Apulian coasts. $\mathrm{Pb}$ contamination is very meaningful lower along the Apulian coast than the other 2 sites considered. The study we performed shows that the trend of metal bioaccumulation in bivalve molluses was not clearly univocal: no one geographical zone showed an accumulation higher than of any other, at least for the metal considered.

The use of bio-indicators turned out to be very valuable for the study of a coastal area, because the 
necessary prerequisites for this purpose they have: they are easy to sample, are available all year round, and are present in every coastal areas of the Mediterranean Sea. Finally, this study wants to contribute to delineate the heavy metal background pollution level and to keep in control the temporal modification of this state.

\section{Acknowledgements}

The authors thank M. D'errico for the contribute he has provided.

\section{References}

Conti M E and Cecchetti G., A biomonitoring study: trace metals in algae and molluscs from Tyrrhenian coastal areas. Environmental Research 2003; 93, 99-112

Eister R. Trace metal concentration in Marine Organism. Oxford Pergamon Press 1981; 685
EN 13805:2002 Determination of trace elements Pressure digestion

EN 15763:2009 Determination of Arsenic, Cadmium, Mercury and Lead in foodstuffs by ICP-MS after pressure digestion

Hedouin L. et al. Influence of food on the assimilation of selected metals in tropical bivalves from New Caledonia lagoon: quantitative and qualitative aspects. Marine Pollution Bulletin 2010; 61, 568-575

Mendez L. et al. Heavy metals in clams from Guaymas Bay, Mexico. Bulletin Environmental: Contamination and Toxicology 2002, 68, 217-223

Oliveira J. et al., Microbial contamination and purification of bivalve shellfish: Crucial aspects in monitoring and future perspectives - A mini review. Food Control 2011; 22, 805-816

Rainbow P. S., Biomonitoring of heavy metal availability in marine environment.. Marine Pollution Bulletin $1995 ; 31,183-192$. 